\title{
PESQUISA E ENFERMAGEM
}

A ciência é algo mais do abstração: fornece-nos uma riqueza de informações sobre as coisas vivas aumentando imensamente o deleite que ela nos proporciona. Valoriza o homem e seu mundo. llumina a beleza da ordem natural e expressa essa beleza na ordem de suas próprias teorias. 0 cientista estuda a natureza não simplesmente porque isso é útil, mas porque se delicia nessa tarefa. Ele descortina o belo na harmonia das partes da natureza que a sua mente pode apreender.

Nenhum cientista isolado pode descobrir tudo o que há para se saber acerta da natureza. Mesmo que pudesse, as suas descobertas seriam destituídas de valor para os outros. Assim, a Ciência é necessariamente um empreendimento social. O cientista depende de uma comunidade profissional e contribui para ela.

A comunidade científica é uma associação de pessoas que não estão vinculadas entre si por leis ou cadeias de comando - não há hierarquias - mas pela comunicação de informações: revistas especializadas, simpósios, encontros, seminários, publicações várias. As sociedades científicas criam e mantêm canais de comunicação em que são apresentadas e avaliadas as alegações de conhecimento. As associações profissionais controlam o ingresso nas sociedades, defendem a ética profissional e representam a profissão junto ao público.

Para uma profissão a pesquisa é fundamental, pois orienta sua ação, revela seu objeto, forma e recicla seus componentes. Toda atividade tem uma recionalidade. Mas esta racionalidade não transparece diretamente; ela só é revelada ao homem que a pode ler conhecendo a linguagem conceitual correspondente.

A enfermagem é constituída de fatos e fenômenos que se realizam todos os dias; mas sua verdade e sua racionalidade só se manifestam para quem as pode ler com as categorias correspondentes.

Pelas suas características e complexidade a enfermagem requer várias abordagens. A classificação e a mensuração, características da pesquisa quantitativa, são necessárias, bem como a análise lógica sincrônica e diacrônica, característica da pesquisa qualitativa.

Para evoluirmos em uma assistência de enfermagem aprimorada é necessário que a teoria desenvolva-se a partir das relações reais e concretas que se dão na ação e que a ação, por sua vez não seja um adestramento sem reflexões, mas orientada pela investigação.

Semiramis Melani Melo Rocha

Centro de Estudos e Pesquisa na Enfermagem

Diretoria do CEPEn

R. Bras. Enferm., Brasília, 41 (2): 91-172, abr./jun. 1988 